\title{
IGREJA E ITALIANIDADE: RIO GRANDO DO SUL (1875-1945)
}

\author{
Paulo César Possamai \\ Doutorando em História Social - DH/FFLCH/USP
}

\begin{abstract}
RESUMO: Este artigo analisa a posição adotada pelo clero católico a respeito da política de italianidade entre os imigrantes italianos no Estado do Rio Grande do Sul. Enquanto os carlistas protegiam o nacionalismo italiano entre os colonos e eram favoráveis a uma boa relação entre a Igreja Católica e o Reino da Itália, para os capuchinhos a italianidade era útil para conservar a fé católica entre os colonos, mas eles apoiavam o ponto de vista conservador do Vaticano que via o Estado liberal italiano como o usurpador das terras do papado.
\end{abstract}

PALAVRAS-CHAVE: Igreja, nacionalismo, imigração, colonização, italianidade.

ABSTRACT: This article analyses the position adopted by the catholic clergy concerning the italianità policy among the Italian immigrants in the State of Rio Grande do Sul. While the Carlists protected the Italian nationalism among the colonists and were inclined to a good relationship between the Catholic Church and the Kingdom of Italy, to the Capuchins the italianità was useful to preserve the catholic faith among the colonists, although they also supported the conservative point of view of the Vatican, that the liberal Italian State was the usurper of the papacy lands.

KEYWORDS: Church, Nationalism, Immigration, Colonization, Italianità.

A partir da implantação da Corte portuguesa no Brasil, em 1808, D. João VI incentivou a criação de algumas colônias de imigrantes suíços e alemães nas capitanias do Rio de Janeiro e da Bahia, como parte da sua política de adaptar as antigas estruturas coloniais do Brasil à sua nova condição de sede da monarquia portuguesa. Com a independência, o projeto colonizador tomou impulso, já que buscava-se modernizar o país através da criação de uma classe de pequenos proprietários, ao mesmo tempo em que se procedia ao "branqueamento" da população, buscando desse modo fugir às características do sistema escravocrata que haviam marcado o Brasil durante o período colonial. Nesse período, chegaram ao Rio 
Grande do Sul os primeiros imigrantes alemães, que fundaram a colônia de São Leopoldo, em 1824.

Entretanto, o projeto colonizador levado a cabo pela Coroa foi paralisado quando da abdicação do imperador Dom Pedro I e da tomada do poder pelos latifundiários escravocratas que, através da lei de 15 de dezembro de 1830, retiraram o financiamento à imigração e colonização no país (DREHER, 1984, p. 32). A nível regional, a eclosão da Revolução Farroupilha reteve o fluxo imigratório. De 1830 a 1844 São Leopoldo não recebeu imigrantes, que voltaram a chegar com o fim do conflito (DACANAL, 1992, p. 28).

$\mathrm{O}$ incentivo à imigração européia foi retomado no segundo reinado como uma forma eficiente de fazer frente à crise da mão-de-obra, decorrente das pressões da Inglaterra contra o tráfico negreiro e da conseqüente agonia do sistema escravista. Especialmente interessada na imigração era a oligarquia de São Paulo, cujo interesse maior era obter a mão-de-obra necessária à produção da nova fonte de riqueza da nação, a cafeicultura.

No Rio Grande do Sul, não se tratava de substituir a mão-de-obra escrava pela do imigrante, mas sim colonizar terras devolutas. O governo imperial visava povoar uma região escassamente habitada, que era cobiçada pelas nações vizinhas, ao mesmo tempo em que planejava diminuir o poder dos grandes estancieiros sul-rio-grandenses, a fim de prevenir a repetição de revoltas como a Revolução Farroupilha. Com a fixação dos imigrantes através do sistema de pequena propriedade, o governo também visava promover o abastecimento do mercado interno com produtos agrícolas, ao mesmo tempo em que essa experiência serviria como foco de atração de novos imigrantes ao país, já que muitos daqueles que pensavam tornaremse pequenos proprietários no sul acabaram sendo desviados para o trabalho nas fazendas de café de São Paulo (PESAVENTO, 1990, pp. 46-47).

Quando o governo prussiano adotou restrições à emigração de seus cidadãos ao Brasil, devido aos abusos cometidos no sistema de parceria, o governo imperial passou a buscar imigrantes na Itália, onde então iniciara-se a imigração em massa de camponeses em direção aos países americanos (DACANAL, 1992, p. 57). Devido aos vários problemas relacionados à sua recente unificação, a Itália substituiu a Alemanha como a principal fornecedora de imigrantes durante esse período.

Séculos de fragmentação política criaram profundas diferenças entre as diversas regiões italianas que agora uniam-se formando um novo país com sérios problemas estruturais a serem resolvidos. Mas o novo Estado italiano não limitou-se aos investimentos necessários ao desenvolvimento nacional pois, com o objetivo de igualar-se às grandes potências européias, destinou grandes parcelas do orçamento ao exército e à marinha, como também às campanhas imperialistas na África. Para fazer frente a esses empreendimentos, o governo passou a aumentar os impostos e criar novas taxas, o que dificultou mais ainda a vida de uma população já empobrecida, que desesperada, encontrou na emigração em massa uma solução à miséria em que se encontrava (VILLA, 1993, pp. 167-170).

O descontentamento com o novo regime não se limitava às questões sociais, pois, desde as revoluções européias de 1848, surgiram os primeiros atritos entre a Igreja e o liberalismo. Uma vez que o movimento de unificação da Itália foi liderado pelos liberais, o mesmo não podia deixar de contar com a franca hostilidade do clero católico. Para os jesuítas, o Risorgimento foi um complô organizado pela maçonaria e pelos judeus com o objetivo de destruir a Igreja Católica. Por outro lado, Garibaldi e Mazzini definiam o Papa como "o câncer da Itália" e até mesmo como "assassino da alma" (VILLA, 1993, p. 130).

O pontificado de Pio IX (1846-1878) foi marcado pela retomada de posições conservadoras, da intransigência anti-liberal e do prosseguimento da política de centralização da Igreja em torno da figura do Papa, iniciada por Gregório XVI (1831-1846). Inicialmente tímida, devido à força do regalismo em 
muitos reinos católicos, a política da centralização tomou impulso a partir da crise de 1848 , quando Roma passou a desenvolver uma ação sistemática a fim de reagrupar em torno de um centro único, face ao liberalismo "revolucionário e anticristão", todas as energias católicas (AUBERT, 1975, p. 59).

Em dezembro de 1864, acompanhando a encíclica "Quanta cura”, surgiu o "Syllabus errorum”, um catálogo contendo oitenta posições consideradas inaceitáveis pela Igreja. Algumas delas constituíam heresias manifestas, mas outras vinham de encontro a tudo que ameaçasse o status quo da Igreja, condenando a laicização das instituições, a separação entre a Igreja e o Estado, a liberdade total de culto e de imprensa, a maçonaria, o socialismo, o racionalismo e o liberalismo. O Syllabus satisfez aos católicos conservadores, porém descontentou aos liberais e, entre os não-crentes simbolizou o obscurantismo da Igreja Católica (AUBERT, 1975, p. 42).

Com o avanço do liberalismo na Europa, as tradicionais monarquias católicas encontravam dificuldades em manter os privilégios concedidos à Igreja, que conseqüentemente perdeu a confiança que sempre depositara nas monarquias em defesa do monopólio do catolicismo. Esse era o ponto de partida do movimento de romanização da Igreja que revigorou o ultramontanismo, movimento que nascera da reação contra os excessos do regalismo nos países católicos que submetiam a Igreja ao Estado. Contudo essa reação não soube como evitar seus próprios excessos, sendo que os ultramontanos moderados acabaram sendo vencidos pelos extremistas que visavam instaurar um catolicismo autoritário, centralizado no poder papal. Essa tendência extremada do ultramontanismo tornou-se majoritária durante o Concílio Vaticano I, convocado por Pio IX em 8 de dezembro de 1869.

O desejo de um certo número de bispos, acolhido favoravelmente em Roma, de fazer do Syllabus a base das deliberações conciliares marcou desde seu início a posição pró-ultramontana do Concílio que, em 18 de julho de 1870 votou, pela quase unanimidade dos presentes, a constituição "Pastor aeternus" que instituía o dogma da infalibilidade papal. Com a tomada de Roma pelo exército italiano em 20 de setembro do mesmo ano, Pio IX considerou que a liberdade do Concílio não estava mais garantida e, a 20 de outubro, declarou-o prorrogado sine die. Entretanto, a vitória dos ultramontanos estava garantida (AUBERT, 1975, p. 63-68).

O regime liberal adotado pela Itália unificada criou leis que desagradaram a população tradicionalmente católica da península. O código civil italiano de janeiro de 1866, decretou a separação entre a Igreja e o Estado e o reconhecimento do casamento civil. As terras eclesiásticas, confiscadas pelo Estado não foram objeto da tão desejada reforma agrária, mas sim vendidas a particulares. A supressão dos conventos, que pôs fim a inúmeras obras de caridade, resultou em revoltas como a de Palermo em setembro de 1866, cruelmente sufocada pelo exército. Para manter a ordem na Sicília, o governo teve de iniciar negociações informais com a Máfia $(\mathrm{GOOCH}, 1986)$.

Mas o código civil criado pelos liberais não foi o único ponto de atrito entre a Igreja e o Estado italiano. Muito mais difícil de ser resolvida era a chamada "Questão Romana". Após a ocupação de Roma, as relações entre o Papa e o novo reino foram reguladas pela "Lei das Garantias", a qual baseava-se no princípio de Cavour, "Igreja livre em um Estado livre", que garantia ao pontífice a máxima liberdade no exercício de suas funções como chefe da Igreja Católica. A lei também reconhecia a extraterritorialidade do Vaticano, da basílica de São João de Latrão e da residência de Castel Gandolfo. Embora essa lei não fosse reconhecida pelo Papa, que a julgava uma lei imposta pelo vencedor, ela foi observada unilateralmente pelo Estado italiano (UGO, 1994, p. 111).

Pio IX não aceitou a perda de Roma e, refugiando-se no Vaticano, considerou-se prisioneiro de guerra. Recusando-se a reconhecer o Estado italiano, proibiu aos católicos italianos participar de eleições, 
lançando o non expedit (não é oportuno votar), criando deste modo uma profunda barreira entre os católicos e o governo italiano. Nem mesmo com a morte de Pio IX e Vítor Emanuel, em 1878, a cisão entre a Igreja e o Estado foi superada. Preocupado com o avanço dos socialistas, o governo buscou o apoio dos católicos através do bispo de Placência, Monsenhor Scalabrini, descrito pelos liberais como "um espírito elevado e culto, muito liberal", que desfrutava de grande influência junto ao novo Papa, Leão XIII. Os candidatos apoiados pelos católicos foram vitoriosos e a "culpa" desse fato foi dada a Scalabrini, que foi repreendido pelo Papa. A partir de então o Vaticano radicalizou sua diretiva aos católicos italianos, trocando o non expedit pelo non licet, pelo qual proibia aos católicos toda a participação na política italiana (VILLA, 1993, p. 104-105).

Embora as causas que originaram o fenômeno da emigração em massa na Itália da segunda metade do século XIX estejam principalmente ligadas a fatores econômicos, também é muito importante salientar a influência que a luta entre o Estado e a Igreja Católica tiveram na decisão de emigrar de muitos camponeses, fortemente marcados pelo conservadorismo e pelo espírito clerical.

A maioria dos imigrantes italianos que se instalou no Rio Grande do Sul, a partir de 1875, provinha das regiões italianas do Vêneto, Lombardia e Friuli e ainda do Trentino onde, pelo fato de pertencer aos domínios da Casa de Habsburgo, apesar da maioria da população ser étnica e culturalmente italiana, o movimento emigratório assumiu características próprias com relação à emigração italiana propriamente dita.

Do século XI até 1805, quando foi cedido à Baviera por Napoleão, Trento foi uma cidade-livre do Sacro Império Romano-Germânico, governada por príncipes-bispos. A maioria da população trentina era composta de camponeses (cerca de $90 \%$ da população total), cujo caráter pragmático se preocupava mais com a cobrança das taxas e impostos e com o núme- ro de soldados requisitados pelo governo do que com a nacionalidade dos governantes. Por isso uma das raras rebeliões ocorridas no Trentino aconteceu em 1809, quando o governo bávaro tentou impor a conscrição obrigatória à toda a população masculina da região. A revolta logo recebeu o apoio da Áustria, que ambicionava anexar a província rebelde. A situação foi controlada por Napoleão, que, através do Tratado de Paris, de 1810, transferiu o domínio político do Trentino, da Baviera para o reino napoleônico da Itália.

Com a derrota de Napoleão, a Áustria ocupou a região em 07 de abril de 1815, data marcada pela visita do imperador Francisco I a Trento. Em 1816, o principado de Trento foi anexado à província austríaca do Tirol, passando desde então a chamar-se oficialmente "Tirol Meridional", numa clara tentativa de assimilação, já que o Tirol é uma região caracteristicamente germânica. Naturalmente, essa atitude do governo austríaco provocou descontentamento na população que, em 1848, enviou a Viena um abaixoassinado pedindo autonomia administrativa para o Trentino. O governo austríaco não só ignorou o pedido como, em 1854, proibiu o uso do nome "Trentino" que, a partir de então deveria ser substituído por "Tirol Meridional" ou "Tirol Italiano" (GROSSELLI, 1986, p. 22-28).

Contudo, a luta nacionalista pela unificação do Trentino à Itália era uma preocupação marcadamente burguesa e citadina, já que os camponeses não engajaram-se na luta. O conservadorismo e o clericalismo eram as bases da sociedade trentina, majoritariamente camponesa, por isso a ocupação de Roma em 1870 significou a falta de apoio popular à unificação com a Itália, acusada de usurpar os domínios temporais do Papa. O jornal católico "Voce Cattolica" assim definiu o liberalismo em 16.09.1870: "Il liberalismo, come vedemmo, altro non è in sostanza che la ribellione sistematizzata a Dio Creatore e Redentore nell' ordine naturale e soprannaturale; altro non vuole, che la scristianizzazione dell'individuo, della famiglia 
e della società, e la distruzione della Chiesa Cattolica" (apud GROSSELLI, 1986, p. 33).

Essa posição anti-liberal do clero e, por sua influência, da maior parte da população do Trentino, marcou os imigrantes trentinos no Brasil, onde faziam questão de diferenciar-se dos "italianos" como "tiroleses", não tanto por nacionalismo austríaco ou fidelidade à Casa d'Áustria mas, sim por não pertencer a um país condenado pela Igreja pelo seu liberalismo anti-clerical. De fato, a Igreja Católica foi para o campesinato trentino, como também para o italiano, o que o Estado nacional foi para a burguesia emergente e o que foram os sindicatos e os partidos políticos para o proletariado urbano. Na Igreja se formavam os quadros dirigentes do campesinato, para o qual o padre não era somente um sacerdote, mas também um líder intelectual. A moral camponesa era a moral católica e a verdadeira autoridade reconhecida por essa grande parcela da população era o clero (GROSSELLI, 1986, p. 142).

A emigração em massa não se explica, pois, somente pela fuga à pobreza e, por vezes, à miséria em que viviam os camponeses italianos e trentinos. Sob a liderança do clero, os emigrantes buscavam reconstruir na América uma sociedade que passava por profundas transformações na Europa em consequiência do avanço das idéias liberais e socialistas, da urbanização crescente, da industrialização e do militarismo (GROSSELLI, 1986, p. 145-154). A fim de fugir da nova ordem, uma parte do clero acalentou o ideal de reconstruir no Novo Mundo uma sociedade camponesa e clerical. Um sacerdote da província italiana de Treviso chegou a afirmar "que estando a religião em decadência na Itália, justificava-se emigrar para a América a fim de aí estabelecer-se uma colônia piedosa" (DORE, apud AZEVEDO, 1975, p. 63).

A emigração em busca de trabalho em países vizinhos já era tradicional entre os habitantes do norte da Itália e do Trentino, porém, com a chegada dos agentes de imigração às aldeias italianas retratando os países americanos como um verdadeiro Éden, surgiu uma verdadeira "febre americana" entre os camponeses italianos. A emigração desse período não foi um fenômeno individual, mas de grupo, e, se esse verdadeiro êxodo se desenvolveu num clima relativamente pacífico, isso foi devido à influência do clero, que procurou evitar o surgimento de tensões entre as classes sociais no momento da partida, que, por vezes se assemelhava a uma grande procissão, quando os emigrantes seguiam o caminho para o porto de embarque acompanhados pelo som dos sinos, precedidos por um cruz ou o estandarte de um santo (VILLA, 1986, p. 75-76).

Nesses grupos de emigrantes partia tanta gente que, por vezes, a inteira população de uma aldeia decidia emigrar em conjunto, situação dramática que levou muitos párocos a aderir e mesmo liderar o movimento emigratório. Entre os padres que acompanharam grupos de emigrantes encontramos o padre trentino Bartolomeu Tiecher que, em 1875, partiu rumo ao Brasil na companhia de um grupo de 208 imigrantes italianos e 392 trentinos, entre os quais se encontravam seus pais e irmãos. Chegando ao Rio Grande do Sul, o padre Tiecher foi nomeado pelo governo imperial capelão da Colônia de Santa Maria da Soledade do Farromeco. Em 1886 tornou-se vigário da recém-criada paróquia de Garibaldi (RUBERT, 1977, p. 47-50).

O padre Domenico Munari, pároco de Fastro, diocese de Pádua, ofereceu-se para emigrar junto com seus paroquianos e, em 1876, partiu com um grupo de 275 imigrantes italianos que embarcaram em Bordéus, na França, rumo ao Brasil. Apesar do navio em que viajavam ter naufragado próximo a $\mathrm{La}$ Rochelle, ele e seu grupo retomaram a viagem ao Rio Grande do Sul, onde Munari estabeleceu-se como o primeiro pároco de Bento Gonçalves (RUBERT, 1977, p. 51-53).

A presença de um sacerdote entre os imigrantes dava-lhes um sentimento de segurança e de bênção ao 
movimento emigratório, aumentando a identificação entre o campesinato e o baixo clero. Contudo, o mesmo sentimento não se repetia com relação ao alto clero, que identificava-se com as classes dominantes. Quando o bispo de Crema, na província de Cremona, pediu aos presentes à missa que pensassem seriamente sobre a decisão de emigrar, exortando os fiéis a não desesperarem-se, um após outro, os camponeses abandonaram a igreja de Cascine Gandine, deixando o bispo só. Para esses camponeses, seduzidos pelo sonho de fare l'America, o bispo estava a serviço dos patrões (VILLA, 1993, p. 81).

Entre os agentes de emigração encontrava-se um padre, que da central de recrutamento no Canal do Brenta, próximo a Bassano, havia enviado ao Brasil, em 1877, mais de dois mil camponeses vênetos. A maioria deles seguiu com destino ao Paraná (VILLA, 1993, p. 75). A escolha de um sacerdote para o cargo de agente de imigração certamente tinha como objetivo aproveitar a confiança que os camponeses depositavam no clero, sentindo-se assim, mais seguros para tomar a difícil decisão de emigrar para um país estranho.

Observa-se então que o prestígio que o clero desfruta até hoje entre os descendentes dos imigrantes italianos no Rio Grande do Sul tem sua origem na Itália, particularmente no Vêneto, onde os padres jamais deixavam "de assumir os dramas decorrentes da política, da ocupação estrangeira e das convulsões causadas pela guerra" (BAREA, 1995, p. 11). Mas, se no norte da Itália a influência dos párocos sobre os camponeses era limitada pelas autoridades eclesiásticas e governamentais, além da presença de grupos de maçons, liberais e socialistas, nas colônias do Rio Grande do Sul, freqüentemente isoladas, os padres puderam desenvolver seu poder sem grandes obstáculos (GROSSELLI, 1984, p. 504).

A liderança e papel moralizador do clero entre os italianos foram observados por Manoel Maria de Carvalho, Inspetor de colonização, que escrevia ao governo imperial em 1885: "É por todos sabido que os imigrantes europeus são excessivamente religiosos e não dispensam, de modo algum, o padre e a igreja. Quem conhece, sobretudo por observação própria, as colônias do Império sabe perfeitamente que o padre é o mais poderoso elemento de ordem, moralidade e estabilidade para os colonos. Por este motivo, os chefes das comissões encarregadas de estabelecê-los aproveitam-se dele, como auxiliar indispensável para conseguir que os imigrantes recém-chegados povoem os núcleos novos, dediquem-se ao trabalho agrícola com perseverança, obedeçam às suas determinações e não abandonem os lotes" (apud MANFROI, 1975, p. 182).

Com a avanço da colonização, as terras nas colônias que dispunham de igreja e de pároco eram mais valorizadas que as que não dispunham de serviço religioso permanente em suas proximidades. Em 1884, o Inspetor imperial de colonização declarava: "Tenho o dever de declarar, nesta ocasião, que há grande relutância nos imigrantes em tomar lotes na colônia de Alfredo Chaves, não obstante a excelente qualidade de suas terras e a amenidade do clima, por não encontrarem, nela, padre e igreja. Preferem ficar sem lotes e agregados em pedacinhos de terras dos colonos de Conde d'Eu e D. Isabel, o que é muitíssimo inconveniente à colonização, a seguir para aquela colônia enquanto não houver esse melhoramento" (apud MANFROI, 1975, p. 181). Quando uma comunidade não dispunha de pároco, não poupava esforços para obtê-lo. Sob a liderança de Paulo Bortoluzzi, a comunidade de Vale Vêneto enviou, em 1879, Antônio Vernier à Itália com a missão de obter padres para a região, comprometendo-se em pagar as passagens e sustentar economicamente os padres que aceitassem o pedido (BONFADA, 1991, p. 21-38).

A principal fonte de poder e prestígio do clero entre os colonos era o caráter sobrenatural desse mesmo poder. "Acreditavam que o padre pode garantir a salvação de sua alma e a proteção de seu corpo, através das bênçãos. Logo, a função do padre tornase carregada de valores exteriores à sua própria pessoa, pois deve proteger a ordem tradicional, benefi- 
ciando os bons e castigando aqueles que tentaram romper com os elos pré-estabelecidos pela ordem divina" (MERLOTTI, 1979, p. 92).

Mas, como foi visto anteriormente através das observações do Inspetor de colonização, o prestígio do clero não provinha somente de suas funções sacerdotais, pois também se originava do seu reconhecimento pelos colonos, que geralmente eram analfabetos, como o líder intelectual da comunidade. O correspondente da associação "Italica Gens" observou que: "O espírito religioso se reflete em todos os momentos da vida desta colônia: por isso o sacerdote ocupa um lugar de destaque. Desconheço outros lugares onde o sacerdote possua uma idêntica autoridade. Isto provém do fato de que o sacerdote seja a única pessoa com certa instrução e que se ocupa desinteressadamente dos problemas dos colonos" (VERONESI apud D'APREMONT e GILLONNAY, 1976, p. 193).

Nessa sociedade de pioneiros isolados na floresta, o padre muitas vezes não era somente o médico da alma mas também do corpo, pois geralmente dispunha de medicamentos que administrava aos seus paroquianos. Especialmente preciosas eram as injeções anti-ofídicas, já que, durante a derrubada da mata sempre havia o risco da ocorrência de picadas de cobras: "O sacerdote é o conselheiro dos colonos em qualquer assunto, até em problemas de ordem material. Quando alguém adoece, o sacerdote é chamado antes do médico e nada se faz sem seu parecer" (VERONESI apud D'APREMONT e GILLONNAY, 1976, p. 194)

Os padres também eram líderes políticos e, às vezes, até mesmo líderes partidários como o padre Mateus Pasquali que, durante a Revolução Federalista apoiou decididamente os republicanos, tendo que se refugiar no alto da torre da igreja matriz por ocasião da invasão de Veranópolis por tropas federalistas em 1894 (BUSATA e STAWINSKI, 1979, p. 9).

Não é de admirar que o sonho de muitos filhos e filhas de colonos era o de pertencer ao clero, não só devido aos fatores religiosos, mas também à ascensão social que isso representava, sendo que essa era a única forma de ingresso à vida intelectual, representada pelos conventos e seminários. Ter um filho clérigo era a maior fonte de alegria e prestígio para um colono, mas nem todos eram aceitos na vida religiosa: "Essere prete o suora aveva il suo prezzo: solo i migliori delle migliori famiglie. I bambini dovevano essere graziosi, sani, intelligenti. Deficienti di qualsiasi tipo erano fuori discussione" (TOMELIN apud GROSSELLI, 1986, p. 510).

O catolicismo foi, pois, a força que cimentou a unidade das comunidades italianas no Rio Grande do Sul. "A Religião Católica foi, sem dúvida, a força que permitiu aos imigrantes italianos se integrarem no novo ambiente e formar aquela solidariedade indispensável para enfrentar todas as dificuldades materiais e psicológicas dos primeiros tempos. Eles não tinham um espírito de associação, uma consciência étnica ou nacionalista capaz de os unir ou motivar a solidariedade. Foi em torno da religião e da expressão de seus sentimentos religiosos que eles encontraram a própria identidade cultural, único meio capaz de evitar o desajustamento social" (MANFROI, 1975, p. 139).

Mas, se o baixo clero interessou-se logo pelo movimento emigratório, a cúpula da Igreja só começou a preocupar-se com o êxodo em massa que ocorria na Itália por volta de 1880, uma vez que os governos italiano e austríaco procuraram deter a corrente emigratória através de restrições, mas não se preocuparam em melhorar as condições de vida do campesinato em sua pátria nem em proteger os seus súditos no exterior. Em um congresso realizado em Nápoles, em 1883, Leão XIII encorajou o fundador da St. Raphaels Verein, que se dedicava ao auxílio aos emigrados católicos alemães, a fundar uma filial da organização que seria dirigida aos imigrantes italianos. No mesmo ano, o Papa enviou cartas aos arcebispos de Nápoles, Gênova e Palermo, incentivando-os a prestar assistência aos emigrantes nos portos de embarque. Com esse 
objetivo foram constituídas comissões, mas não se chegou a nada de concreto (ROSOLI, 1975, p. 60).

À falta de apoio concreto aos emigrantes, tanto por parte do governo italiano como da cúpula da Igreja, clérigos e leigos católicos responderam com a criação de uma Congregação de missionários para os emigrados, fundada pelo bispo de Placência, D. Giovanni Battista Scalabrini, em 1877. Sob inspiração do bispo de Cremona, D. Geremia Bonomelli, foi criada uma obra de assistência aos operários emigrados em 1900. Um intelectual católico, Ernesto Schiaparelli, criou a "Italica Gens" que, dependente da Associação Nacional para os Missionários Italianos, se propôs a assistir aos emigrantes na América (GROSSELLI, 1986, p. 168).

D. Giovanni Battista Scalabrini, fundador da Congregação dos Missionários de São Carlos Barromeu, foi uma das personalidades mais marcantes da Igreja no século XIX. Dedicou sua vida à promoção social de operários e agricultores e à reconciliação entre a Igreja Católica e o Estado italiano, mas foi a sua luta pela assistência religiosa e social aos emigrantes italianos que o celebrizou. Sensibilizado com o triste espetáculo das multidões de camponeses que, muitas vezes iludidas por recrutadores inescrupulosos, partiam para a América em busca de melhores dias e assustado com os relatos da falta de assistência religiosa e social nas novas pátrias dos emigrantes, Scalabrini alimentou o desejo de criar um instituto que desse amparo aos seus concidadãos emigrados.

Comparando a emigração italiana com as demais correntes emigratórias européias, Scalabrini constatou a situação de completo abandono em que se encontravam os italianos no exterior: "Das estatísticas várias vezes citadas, dos relatórios privados e dos fatos publicados de vez em quando pelos jornais, certifico-me de que os nossos compatriotas no exterior são os menos amparados, vítimas frequientes de explorações infames, ou por ignorância ou em boa fé; sendo ainda os que, em suas necessidades ou na busca de seus direitos, menos se preocupam em recorrer às autoridades consulares. Coisas estas que podem provir muito bem do espírito de independência do italiano ou do fato de não estar habituado a considerar o Governo do seu país um tutor natural e eficiente; podem, porém, ser também um indício grave de desconfiança gerada pela negligência e incapacidade usual das autoridades. Desta forma, os nossos compatriotas julgam melhor buscar por si mesmos a solução de seus problemas, ao invés de ficar aguardando a proteção tardia e ineficaz da pátria distante" (SCALABRINI, 1979, p. 60).

Scalabrini conclamava à reconciliação entre a Igreja e o Estado italiano, a fim de que ambos protegessem os italianos no exterior. Contudo, como os atritos entre o Estado e a Igreja não davam sinais de trégua e, dada a falta de interesse do governo italiano em assistir aos italianos no exterior, coube à Igreja esse papel através da criação da "Congregação dos Missionários para os Imigrantes", também conhecida pelo nome de "Instituto Missionário Cristóvão Colombo para os Emigrados Italianos na América", cujo objetivo era "manter viva no coração dos nossos compatriotas emigrados a fé católica, e dentro das possibilidades, buscar seu bem-estar moral e econômico" (SCALABRINI, 1979, p. 118).

Scalabrini sabia que os emigrados não só necessitavam de assistência religiosa mas também social, por isso propunha aos seus missionários a criação de escolas e farmácias, "já que naquelas jovens comunidades o bem não deve nunca andar separado do útil, será conveniente fundar em várias localidades abandonadas, ao lado da igreja e da escola, também dispensários farmacêuticos, orientados pelas religiosas ou pelo sacerdote; este fornecerá aos doentes remédios de uso comum a preços módicos. Assim, concentrar-se-ia ao redor do clero a ação multiforme da assistência religiosa, social e material, e a Igreja de Deus seria abençoada pelas multidões, pois assim como seu Divino Redentor, ela 'passou fazendo o bem e curando a todos"' (SCALABRINI, 1979, p. 218). 
O bispo de Placência era admirador das sociedades de assistência aos emigrados alemães e, como elas, também pensava que a manutenção da língua e dos costumes trazidos pela pátria era indispensável à conservação da pureza da fé entre os emigrados no Novo Mundo: "A língua é um misterioso meio de conservação da fé. Não é fácil explicá-lo. É um fato, porém que, perdendo a língua, facilmente se perde também a fé dos antepassados. Apesar da dificuldade de descobrir suas razões, a experiência nos ensina que, enquanto uma família conserva a própria língua no exterior, dificilmente muda de religião" (SCALABRINI, 1979, p. 218). Esse é o fundamento da política de italianidade defendida por Scalabrini, a defesa da língua e da fé dos emigrantes. No Rio Grande do Sul a Italianità não alcançou a mesma abrangência que o Deutschtum entre os alemães, porém sua importância não deve ser minimizada ${ }^{1}$.

A Congregação fundada por Scalabrini teve início a 28 de novembro de 1887 quando, em Placência, sua sede, os dois primeiros padres fizeram a profissão religiosa qüinqüenal. Em 1896 a Congregação passou a chamar-se, oficialmente, "Congregação dos Missionários de São Carlos" e por isso seus missionários passaram a ser conhecidos como "carlistas" embora a denominação de "scalabrinianos" também seja comum, já que lembra o nome do fundador. O primeiro carlista a chegar ao Rio Grande do Sul foi o padre Domingos Vicentini, que chegou ao Estado em 1896, dedicando-se à comunidade italiana de Encantado. Com a chegada de novos missionários, a atuação dos carlistas se estendeu à várias localidades da região de colonização italiana do Rio Grande do Sul,

\footnotetext{
${ }^{1}$ Sobre a política de germanidade (Deutschtum) entre os imigrantes alemães de Confissão Luterana no Rio Grande do Sul, consultar: Martin Norberto Dreher. Igreja e Germanidade. São Leopoldo: Sinodal; Porto Alegre: EST; Caxias do Sul: EDUCS, 1984, 287 p.
}

justificando a visita do bispo de Placência ao Estado entre setembro e outubro de 1904, quando o prelado visitou Encantado, Garibaldi, Bento Gonçalves, Veranópolis, Nova Prata, Nova Bassano e Caxias do Sul (RIZZARDO, 1981, p. 13).

Para os carlistas ou escalabrinianos, a italianidade ligava o amor à Itália à manutenção da religião católica. Scalabrini defendia a idéia de que a preservação da fé católica estava estreitamente ligada à manutenção da língua, da cultura e dos costumes italianos pelos imigrantes. Mas, para que os imigrantes sentissem a necessidade da preservação de seu patrimônio cultural no exterior era preciso que os mesmos sentissem orgulho pela sua nacionalidade, daí a luta do bispo pela união dos sentimentos de religiosidade e patriotismo: "A Religião e a Pátria choram seus milhões de filhos perdidos. Um povo somente soube resistir à violenta tentativa de assimilação, e este foi quem tinha inscritas em sua bandeira a nossa Igreja, a nossa escola e a nossa língua" (SCALABRINI, 1979, p. 188).

Se, por um lado, Scalabrini flertou com o imperialismo, então em voga na Europa, provavelmente o fez com o objetivo de atrair a atenção do Estado italiano nas vantagens em que o mesmo poderia auferir na preservação do sentimento de italianidade entre os súditos emigrados, bem como na sua proteção. Afirmava que "sem recorrer a conquistas destruidoras a Itália poderia conseguir na América um vasto campo para o desenvolvimento de suas colônias; politicamente, elas não dependeriam da mãe-pátria, - diferentemente das colônias inglesas e francesas; poderiam, porém, ser de grande utilidade para o incremento de seu comércio e de sua legítima influência" (SCALABRINI, 1979, p. 62-63).

Entretanto, Scalabrini deu-se conta de que tal influência sobre os imigrantes poderia ser mal vista pelos governos dos países americanos e o mesmo se pode dizer a respeito de uma rigorosa política antiassimilatória. Por isso, nas suas diretrizes para a ação pastoral junto aos imigrantes, expostas no seu escrito "Aos Missionários para os Italianos nas Américas", 
o Bispo de Placência, diz: "Continuai todos, caros irmãos e filhos, a empregar o que tendes de inteligência e de força na conservação do bem-estar religioso, moral e social dos nossos compatriotas; e ao vos aplicar a manter neles vivo o amor à mãe-pátria, guardaivos de fomentar qualquer coisa que possa separá-los de seus novos concidadãos, ou afastá-los dos outros fiéis. Cabe a vós fazer com que os italianos em nada se distingam, senão pelo respeito maior à autoridade, pela observância mais exata de suas obrigações e pelo devotamento mais profundo à fé de seus antepassados" (SCALABRINI, 1979, p. 153).

Seguindo os ideais de seu fundador, os carlistas distinguiram-se pela política de preservação da italianidade entre os imigrantes italianos e seus descendentes no Rio Grande do Sul, por meio da assistência religiosa, do ensino da língua italiana nas escolas por eles fundadas e também da imprensa, como recomendara o próprio Scalabrini. Fundado pelo padre Henrique Poggi em Bento Gonçalves no ano de 1913, o jornal "Il Corriere d'Italia" passou a ser o porta-voz do pensamento scalabriniano nas colônias italianas do Rio Grande do Sul (RIZZARDO, 1990, p. 177-178).

Em sua visão da colônia italiana no Rio Grande do Sul como um prolongamento ultramarino da Itália, os carlistas promoveram subscrições a favor dos combatentes italianos na Primeira Guerra Mundial e, após o conflito, recolheram e enviaram donativos para a reconstrução nacional (RIZZARDO, 1990, p. 272). Entretanto, o nacionalismo italiano dos carlistas entrou em choque com as novas gerações, pois os descendentes dos imigrantes desejavam assumir a sua condição de cidadãos brasileiros, fazendo com que os carlistas se retirassem de Bento Gonçalves “já que o povo, sobretudo os jovens, sentindo-se cada vez mais brasileiros, viam em cada religioso do Instituto de Placência simplesmente um italiano, o que significava uma volta ao passado" (RIZZARDO, 1990, p. 191).

Outra ordem religiosa que se destacou na assistência aos imigrantes italianos e seus descendentes no
Rio Grande do Sul foi a dos capuchinhos, cuja tradição missionária levou o terceiro bispo de Porto Alegre, D. Cláudio José Gonçalves Ponce de Leão, a empenhar-se na sua vinda ao Estado, pois desejava que uma Ordem religiosa se ocupasse da assistência religiosa aos imigrantes italianos, da mesma forma que os jesuítas se ocupavam dos alemães.

Quando bispo de Goiás, Dom Cláudio acompanhara o trabalho missionário que os capuchinhos italianos desenvolviam no centro e no norte do Brasil. Contudo, a busca de missionários entre as províncias capuchinhas da Itália revelou-se infrutífera, pois as mesmas não dispunham de pessoal suficiente, já que estavam engajadas em outros projetos missionários. D. Cláudio não se deu por vencido e recorreu ao próprio Papa, Leão XIII, que encaminhou o seu pedido ao Ministro Geral dos Capuchinhos, o qual, por sua vez, apelou ao Ministro Provincial da Sabóia, já que o mesmo estava ciente dos problemas que essa província enfrentava devido à política anti-clerical desenvolvida pelo governo francês.

Em cinco de dezembro de 1895, o Provincial, frei Rafael de la Roche, acompanhado pelos freis Bruno de Gillonnay e León de Montsapey embarcaram em Bordéus rumo ao Brasil. Em dois de janeiro do ano seguinte, os freis chegaram ao porto de Rio Grande. Após breve estada em Porto Alegre, seguiram para Garibaldi. Em 1898, acompanhando os estudantes de Teologia, foi enviado ao Brasil frei Bernardin d'Apremont. A princípio, d'Apremont dirigiu os estudos de Teologia em Garibaldi, passando depois a lecionar no seminário diocesano de Porto Alegre.

A fim de manter economicamente as missões e os conventos dos capuchinhos, D. Cláudio lhes cedeu as paróquias de Vacaria e Flores da Cunha em 1903, Veranópolis em 1904, Lagoa Vermelha em 1908 e Sananduva em 1911. Além de seu trabalho nas missões e nas paróquias, os capuchinhos franceses dedicaram-se à catequese dos indígenas da paróquia de Lagoa Vermelha e, de 1903 a 1913, administraram o 
seminário diocesano de Porto Alegre (ZAGONEL, 1975, p. 199-266).

Devido à sua nacionalidade francesa, os capuchinhos enfrentaram a oposição dos nacionalistas italianos ao seu trabalho missionário entre os imigrantes italianos e seus descendentes. Essa oposição, por parte dos católicos, se concentrou nos padres carlistas e nos representantes da associação católica "Italica Gens", a eles ligada. Em sua visita ao Rio Grande do Sul, em 1904, Scalabrini teria dito aos capuchinhos: "Vosso dever é de evangelizar os bugres, isto é: deixai os italianos para os italianos" (MONTSAPEY, apud ZAGONEL, 1975, p. 179).

Os capuchinhos também foram acusados de fazer propaganda francesa entre os italianos e seus descendentes. Com efeito, frei Bruno de Gillonnay pediu ao vice-cônsul francês a recomendação da missão dos religiosos franceses no Rio Grande do Sul como sendo de utilidade para a França, argumentando que "os Irmãos e Irmãs francesas, com seu magistério, ensinarão a estimar a França; seu devotamento e sua virtude dará a esta população uma exata idéia do caráter francês" (GILLONNAY, apud ZAGONEL, 1975, p. 180).

De fato, a influência francesa entre os colonos se fez presente por meio da introdução de costumes religiosos que imitavam os modelos franceses, como por exemplo na organização das cerimônias de Primeira Comunhão, na tradução para o italiano de preces e cantos religiosos franceses e na divulgação da devoção ao Sagrado Coração de Jesus. Também a arquitetura religiosa reflete a influência dos frades da Sabóia na disseminação do estilo neogótico. A igreja matriz de Flores da Cunha foi projetada na França a pedido dos frades e, mesmo que o estilo neogótico não fosse do agrado da maioria dos italianos, os capuchinhos souberam convencê-los a mudar de idéia: "Era necessário conseguir a aprovação da população que não se agradava desse gênero de arquitetura. Não foi fácil, mas o fizeram com tanta felicidade que despertaram um grande entusiasmo nos paroquianos. Foi renovado e durou por muitos anos o empenho e o devotamento que outrora se manifestara na construção do convento" (D'APREMONT e GILLONNAY, 1976. p. 233).

Mas, mesmo sendo franceses, os capuchinhos também destacaram-se pela defesa da italianidade entre os imigrantes. Naturalmente o seu esforço em prol da italianidade diferia do que era desenvolvido pelos missionários carlistas, já que os capuchinhos tinham outra concepção dessa política. Da mesma forma que os carlistas, os frades acreditavam que a preservação da cultura e língua italianas era necessária à manutenção da fé católica entre os imigrantes $\mathrm{e}$ seus descendentes, mas não defendiam a vinculação dos mesmos ao Estado italiano, pois este era visto como um inimigo da Igreja Católica. Nesse sentido, sua posição não se diferenciava da dos franciscanos alemães entre os imigrantes italianos de Rodeio, em Santa Catarina, onde os mesmos "ensinavam em italiano para preservar os imigrantes do indiferentismo luso-brasileiro e do proselitismo evangélico, mas sem nada de patriotismo, já que no currículo pouco havia de Itália e muito de História Sagrada e de Catecismo" (SAVÓIA, apud DE BONI, 1987, p. 221).

Os capuchinhos estavam conscientes da impossibilidade e do perigo de se tentar criar uma extensão da Itália no Brasil, isolando-a do resto do país: "Devemos também notar que é uma questão muito delicada pretender conservar como oásis isolados as colônias européias estabelecidas no Brasil. Nem tudo é vantagem! O isolamento dos colonos de origem alemã produziu uma irritação difícil de supor, na Europa" (D'APREMONT e GILLONNAY, 1976, p. 89).

Ao mesmo tempo em que defendiam a manutenção da cultura italiana, os capuchinhos não perdiam de vista que a nova pátria dos imigrantes era o Brasil. Portanto, eles deveriam aprender a língua do país de adoção a fim de evitar um isolamento que só lhes traria prejuízos: "Não se pode ensinar somente o italiano, porque os alunos não se apresentariam ou, então, 
ao saírem da escola, não teriam nenhum prestígio e não poderiam ingressar nos grandes estabelecimentos comerciais da zona colonial" (D'APREMONT e GILLONNAY, 1976, p. 182).

Também havia o fato de que nem todos os imigrantes aceitavam a propaganda que certos clérigos faziam da Itália, gerando problemas entre o clero estrangeiro e as autoridades brasileiras: "Não são raros os italianos que procuram a simpatia das autoridades e estão prontos a denunciar a menor palavra do padre, como contrária ao Brasil. Posso apontar um dos nossos padres, denunciado às autoridades do Estado como tendo falado contra o Brasil e, no entanto, ele só demonstrou aos italianos uma simpatia quase excessiva" (D'APREMONT e GILLONNAY, 1976, p. 85). O pragmatismo dos capuchinhos da Sabóia mostrou ser a forma mais adequada para a preservação da italianidade entre os imigrantes e seus descendentes: Preservar a cultura italiana mas cultivar a cidadania brasileira, inserindo-se na nova pátria.

As diferentes visões que carlistas e capuchinhos tinham sobre política de italianidade contribuíram para aumentar a cisão entre os imigrantes italianos que vinham do Reino da Itália dos que vinham de Trento com passaporte austríaco. Tal como entre os imigrantes, o clero de língua italiana também dividia-se entre "italianos" e "austríacos". Com a chegada dos missionários capuchinhos e carlistas, essa divisão tornou-se ainda mais clara, pois os capuchinhos franceses receberam o apoio total dos padres trentinos, enquanto que o clero italiano aprofundou sua cisão em dois grupos, com os nacionalistas vinculando-se aos carlistas e os ultramontanos mantendo sua intransigente posição de defesa do papado e condenação ao reino unificado da Itália.

Com relação aos padres trentinos, Riolando Azzi afirma que: "Havia profunda sintonia entre esses sacerdotes e os frades de Sabóia no exercício do ministério sacerdotal, caracterizada por dois pontos principais: por um lado, a insistência a fim de que os colonos continuassem a manter a língua e os costu- mes de sua região de origem, como instrumento adequado para a manutenção da fé católica; por outro, uma fidelidade irrestrita à Santa Sé, em sua postura de condenação da unificação italiana e do governo constitucional daí resultante. Na perspectiva da Cúria Romana, o governo da Itália era apenas um instrumento manobrado por liberais e maçons, e por ela condenado. Assim sendo, havia simpatia natural pelo Império Austríaco, cuja orientação política se afinava melhor com as diretrizes marcadamente conservadoras da Santa Sé" (AZZI, 1990, p. 65).

O local escolhido pelos capuchinhos da Sabóia para sua instalação, quando da sua chegada ao Rio Grande do Sul, foi Garibaldi, onde receberam a doação de uma casa oferecida pelo padre trentino Bartolomeu Tiecher. Os frades também receberam o apoio incondicional dos párocos de Garibaldi, João Batista Fronchetti, e de Flores da Cunha, Augusto Finotti, ambos trentinos.

A controvérsia entre os missionários das duas Ordens religiosas foi levada à imprensa nas disputas entre os jornais "Il Corriere d'Italia", dirigido pelos carlistas em Bento Gonçalves, e "Il Colono Italiano", fundado pelo padre Fronchetti em Garibaldi, sob a influência dos capuchinhos, que assumiram a sua direção em 1921. Fronchetti chegou a exercer o cargo de vice-cônsul da Áustria e, em 18 de agosto de 1911, foi condecorado com a comenda da Cruz de Cavaleiro da Ordem do Imperador Francisco José. Durante a Primeira Guerra Mundial o jornal "Il Colono Italiano" manteve uma postura francamente germanófila, provocando a reação do "Corriere d'Itália" (RUBERT, 1977, p. 82).

A aversão entre os dois grupos transformou-se em hostilidade por ocasião da eclosão da Primeira Guerra Mundial, quando a Itália e a Áustria-Hungria lutaram em campos opostos. Quando morreu o imperador Francisco José, os trentinos mandaram celebrar uma missa fúnebre, mas os italianos roubaram o badalo do sino da igreja matriz de Caxias do Sul para 
impedir os dobres. No dia do Armistício, em 1918, diante das casas dos trentinos e demais súditos austrohúngaros residentes em Caxias do Sul realizaram-se manifestações hostis (AZEVEDO, 1975, p. 218).

Posição sem dúvida excêntrica foi tomada pelo padre João Morelli que, mesmo sendo italiano nato e missionário escalabriniano, fato que só por si deveria indicar sua inclinação à defesa do ideal de italianidade, tão caro a Scalabrini, passou a defender a Áustria após a quebra do tratado da Tríplice Aliança pela Itália, em 1915. Sua atitude exaltou os ânimos em Muçum, onde “a população local, dividida entre 'italianos' da Itália e 'italianos' austríacos (...), ficou praticamente em pé de guerra" (RIZZARDO, 1981, p. 73). A fim de acalmar a população de Muçum, o padre Morelli foi transferido para Nova Bréscia em novembro de 1915.

De fato, se na Europa os trentinos não demonstravam muito entusiasmo com a sua condição de súditos dos Habsburgos, no exterior eram patriotas inflamados, como observou o imigrante italiano Júlio Lorenzoni na Bento Gonçalves de fins do século XIX: "Os trentinos mantiveram sempre a máxima união entre eles e um grande apego e saudade de sua cara Áustria, demonstrando sempre uma certa aversão à Itália e aos italianos. E não podia ser diferente se pensarmos no ambiente do qual haviam chegado e a educação que haviam recebido em sua pátria" (LORENZONI, 1975, p. 170).

Contudo, como já observamos, a hostilidade entre "austríacos" e "italianos" parece ligar-se mais às posições adotadas pela Áustria e pela Itália com relação à Igreja Católica do que ao nacionalismo propriamente dito dos imigrantes. As tumultuadas relações entre a posição conservadora da Igreja Católica e a liberal adotada pelo Estado italiano repercutiram na região de colonização italiana do Rio Grande do Sul, dando origem a diversos conflitos. "A atitude intransigente e ultramontana da Cúria Romana, por sua vez, provocou a reação dos intelectuais italianos, de posição liberal ou anarquista, os quais passaram a ver a assistência religiosa oferecida pela Igreja aos imigrantes como um esforço de impedir a sua conscientização política" (AZZI, 1990, p. 63).

Mas, se a Igreja dominava absoluta, sem a presença de rivais que ousassem contestar seu papel de liderança entre a população rural da região de colonização italiana, não se pode dizer o mesmo com relação aos núcleos urbanos das colônias, onde a presença de representantes de outras ideologias e religiões impediram o monopólio do pensamento católico. O principal grupo que fazia oposição à Igreja era formado pelos maçons que, apesar de serem um grupo bastante reduzido e de dividirem-se em franco-maçons e maçons carbonários, foram os que melhor se adaptaram à política regional e estadual, freqüentando as mesmas lojas maçônicas dos fazendeiros dos Campos de Cima da Serra (GIRON, 1994, p. 42).

Os maçons eram, entre os imigrantes, os intelectualmente melhor capacitados. Defendiam as posições liberais do Estado italiano, promovendo a comemoração das datas nacionais italianas entre os imigrantes, motivos de constantes atritos com o clero ultramontano. Esses atritos geralmente originavam atos de violência entre os líderes dos grupos em conflito. Já no início da colonização muitos padres tiveram de abandonar suas paróquias por correr risco de vida. Entre eles podemos citar os padres Bartolomeu Tiecher, quando pároco de Garibaldi, e Augusto Finotti e Agostinho Magon na paróquia de Caxias do Sul. Os maçons também foram acusados de serem os responsáveis pela misteriosa morte do padre Vítor Arnoffi, primeiro capelão de Silveira Martins (RUBERT, 1977, pp. 47-64).

Embora, em fins do século XIX, o clima de intransigência e de disputa entre os maçons e os ultramontanos fosse comum a todo o território nacional, nas regiões de colonização italiana acrescentouse outro fator a essa luta: o nacionalismo. E, se os maçons eram freqüentemente violentos na sua luta contra o clero ultramontano, este demonstrava sua intransigência boicotando as atividades públicas promovidas pela maçonaria. 
Em 1889, os maçons de Caxias do Sul programaram uma festa para comemorar o vinte de setembro, data da tomada de Roma e, numa clara provocação ao clero, convidaram os padres a participar da mesma. O padre palotino Henrique Vieter, então pároco de Caxias, revidou: "Em todas as missas explicou ao povo que a tomada de Roma significou, na verdade, a usurpação dos Estados Pontifícios. Era, portanto, uma afronta ao Papa. Não convinha, pois, que os fiéis participassem (...) E para esvaziar a comemoração, celebraram na mesma data, com maior solenidade, a festa da padroeira Santa Teresa, com missa solene e procissão" (BONFADA, 1991, p. 76-78).

O mesmo padre se destacou pela sua luta na "cristianização" dos nomes próprios demasiadamente ligados ao nacionalismo italiano para serem aprovados pelo clero ultramontano: "Os italianos muitas vezes davam o nome de Ítalo aos meninos, e Itália às meninas, e contra isso nada se podia fazer. Para evitar longas discussões eu lhes dizia: 'tomemos São José por protetor', e batizava o menino com o nome de José Ítalo. As meninas também merecem uma grande padroeira, e lhes dava o nome de Maria Itália, com o que os colonos se sentiam muito satisfeitos" (VIETER, apud BONFADA, 1991, p. 73).

Os atritos entre a Igreja e a maçonaria cresceram com a reorganização da loja "Força e Fraternidade" em 1894. Na tentativa de deter o avanço dos maçons foi enviado a Caxias do Sul o padre Pedro Nosandini, que criou comitês ou ligas católicas em vários travessões da região colonial italiana. Considerados pelo governo italiano como focos de anarquia, esses comitês tinham por objetivo agrupar as forças favoráveis à devolução dos Territórios Pontifícios ao Papa. Com a criação das ligas, as lutas entre católicos e maçons tornaram-se cada vez mais violentas, com atentados contra os líderes dos dois grupos. A pacificação deu-se com a intervenção do governo estadual, que fechou algumas lojas maçônicas e obteve do bispo a transferência do padre Nosanoini (GIRON, 1994, p. 43-55).
Com a ascensão do fascismo na Itália houve uma mudança radical na atitude do governo italiano em relação aos emigrados e seus descendentes. Se antes eles estavam praticamente abandonados pelo Estado italiano, agora, numa tentativa de cooptação elaborada pelo regime fascista, eram reconhecidos como "italianos no exterior". Vantagens comerciais oferecidas à burguesia regional, reconhecimento do sucesso individual dos imigrantes através de condecorações e a intensa propaganda fascista difundida pelas sociedades italianas e pelas escolas subvencionadas pela Itália, ao lado de uma intensa programação cultural visando a difusão da língua italiana e dos ideais fascistas, levaram a uma revalorização da italianidade entre a população da região colonial italiana do Rio Grande do Sul (GIRON, 1994, p. 81-113).

O principal agente divulgador da "Jovem Itália" na região colonial foi a Igreja Católica, já que, graças aos acordos de Latrão, assinados em 1929, Mussolini resolveu a espinhosa "Questão Romana", que, desde 1870, dificultava as relações entre a Igreja e o Estado italiano. Com a criação do Estado do Vaticano, o prestígio obtido por Mussolini não se restringiu à Itália, mas alcançou todo o mundo católico, difundindo-se na região colonial italiana por meio da pregação do clero e da imprensa católica.

Na comemoração dos dez anos de implantação do regime fascista, o jornal do capuchinhos, o "Staffetta Riograndense", descreveu Mussolini como "um herói que luta em defesa de uma nova era de paz, traz um espada em sua mão para combater os inimigos (maçonaria e socialismo) e desarmá-los" (apud GIRON, 1994, p. 94). Se, antes o inimigo principal da Igreja era a maçonaria, agora a luta maior se dava contra o comunismo. Dentro dessa perspectiva o "Duce" era visto pelo clero como o herói que havia salvado a Itália da anarquia e do comunismo.

Em 1928, criou-se uma comissão pró-criação do bispado de Caxias do Sul a partir de um movimento iniciado pelo clero regional. Essa comissão era lidera- 
da pelo prefeito municipal, Celeste Gobatto, que também era um importante líder fascista em sua cidade. Apesar de não contar com o apoio do arcebispo, D. João Becker, em 1935 a criação da nova diocese foi confirmada pela Santa Sé: "Na luta pela diocese, a italianidade apareceu em diversos modos: interesse consular, luta por um mapa que tivesse os contornos da colônia italiana, tática de apoiar a criação de Vacaria para evitar ser diocese de campanha, desejo de municípios coloniais por integrar o mapa". A influência dos fascistas na criação da nova diocese levou frei Pacífico, coordenador dos trabalhos da comissão pró-diocese de Vacaria, a desabafar: "Mussolini, depois de ter conquistado a Abissínia, conquistou o Rio Grande do Sul" (PINZETTA, 1996, p. 546-547).

Se a Revolução de 1930 sofreu duras críticas por parte do clero da região colonial italiana, o mesmo não aconteceu quando da implantação do Estado Novo, que recebeu a fervorosa adesão de uma considerável parcela de clero regional. Na medida em que o Brasil se distanciava do Eixo e passava para o campo dos aliados, a Igreja ia adequando-se à nova situação ao apoiar Getúlio Vargas e ao abandonar a pregação pró-fascista (GIRON, 1994, p. 93).

Em 1939, a diocese de Caxias do Sul, baseada nas determinações da arquidiocese de Porto Alegre, resolveu "nacionalizar" as práticas religiosas, determinando que: "todos os sermões e práticas religiosas devem ser feitos em língua portuguesa; ao final dos sermões poderá ser feito um pequeno resumo na língua estrangeira, se houver grande número de fiéis que não entendam o português; na região onde só houver italianos, a língua deverá ser o vernáculo, utilizando um resumo final em língua italiana; se os padres não souberem o português podem copiar discursos e sermões já realizados" (apud GIRON, 1994, p. 131).

Com essas medidas, o bispo buscava enquadrar sua diocese na nova situação política, pois, desde 1938, uma série de decretos do governo federal passaram a restringir as atividades dos estrangeiros no país, especialmente as que diziam respeito à sua atuação política. Em janeiro de 1942, após a o rompimento das relações diplomáticas e comerciais do Brasil com os países do Eixo, aumentaram as pressões contra os italianos, alemães e japoneses no país, que, entre outras restrições, tiveram suas associações dissolvidas e foram proibidos de falar em lugares públicos no próprio idioma (CORSETTI, 1987, p. 376-377).

No entanto, sem grandes traumas, a Igreja soube ajustar-se às mudanças ocorridas na política internacional e nacional, mantendo seu papel de liderança na sociedade colonial italiana, continuando a representar a principal força de identificação, num momento em que a preservação dos valores e tradições italianos foi posta em xeque pelo Estado Novo. 


\section{Bibliografia}

AUBERT, Roger. "A Igreja na Sociedade Liberal e no Mundo Moderno". In ROGIER, L. J. et alii. Nova História da Igreja. Petrópolis, Vozes, 1975, v. 5, t. 1, 262p.

AZEVEDO, Thales de. Italianos e Gaúchos: Os Anos Pioneiros da Colonização Italiana no Rio Grande do Sul. Porto Alegre, A Nação - Instituto Estadual do Livro, 1975, 310p.

AZZI, Riolando. "Fé e Italianidade: A Atuação dos Escalabrinianos e dos Salesianos Junto aos Imigrantes", In DE BONI, Luís A. (Org.). A Presença Italiana no Brasil. Porto Alegre, EST, 1990, v. 2 , p. $63-80$

BAREA, José. A Vida Espiritual nas Colônias Italianas do Estado do Rio Grande do Sul, Porto Alegre, EST, 1995, 104p.

BONFADA, Genésio. Os Palotinos no Rio Grande do Sul. Porto Alegre, Palotti, 1991, 243p.

BUSATTA, Félix Fortunato e STAWINSKI, Alberto Victor. Luís de la Vernaz: A Igreja em Colônias Italianas. Porto Alegre, EST; Caxias do Sul, UCS, 1979, 221p.

CORSETTI, Berenice. "O Crime de Ser Italiano: A Perseguição do Estado Novo”. In: DE BONI, Luís A. (Org. ). A Presença Italiana no Brasil. Porto Alegre. EST, 1996, v. 1, pp. 363-382.

DACANAL, José H. (Org.). RS: Imigração e Colonização. $2^{\mathrm{a}}$ ed. Porto Alegre: Mercado Aberto, 1992, 280p.

D'APREMONT, Bernardin e GILLONNAY, Bruno. Comunidades Indígenas, Brasileiras, Polonesas e Italianas no Rio Grande do Sul. Porto Alegre: EST; Caxias do Sul: UCS, 1976, 267p.

DE BONI, Luís A. "A Colonização no Sul do Brasil Através do Relato de Autoridades Italianas". In DE BONI, Luís A. (Org.). A Presença Italiana no Brasil. Porto Alegre, EST, 1987 , v. 1, p. 202-223.

DREHER, Martin Norberto. Igreja e Germanidade. São Leopoldo, Sinodal, 1984, 287p.

FRANZINA, Emilio. Storia dell'Emigrazione Veneta: Dall'Unità al Fascismo. Verona, Cierre, 1991, 170p.
GIRON, Loraine Slomp. As Sombras do Littorio: O Fascismo no Rio Grande do Sul. Porto Alegre, Parlenda, 1994, 171p.

GOOCH, John. A Unificação da Itália. São Paulo, Ática, 1991, 69p.

GROSSELlI, Renzo M. Vincere o Morire: Contadini Trentini (Veneti e Lombardi) Nelle Foreste Brasiliane. Trento, Effe e Erre, 1986, 647p.

LORENZONI, Júlio. Memórias de Um Imigrante Italiano. Porto Alegre, Sulina - PUCRS, 1975, 264p.

MANFROI, Olívio. A Colonização Italiana no Rio Grande do Sul: Implicações Econômicas, Políticas e Culturais. Porto Alegre, Grafosul - Instituto Estadual do Livro, 1975, 218p.

MERLOTTI, Vania B. Pisani. O Mito do Padre Entre os Descendentes Italianos. 2. ${ }^{\mathrm{a}}$ ed. Porto Alegre, EST; Caxias do Sul: UCS, 1979, 103p.

PESAVENTO, Sandra Jatahy. História do Rio Grande do Sul. 5. ${ }^{2}$ ed. Porto Alegre, Mercado Aberto, 1990, 141p.

PINZETTA, Álvaro Luiz. "Criação da Diocese de Caxias do Sul (8.9.1934)”. DE BONI, Luís A. (Org.). A Presença Italiana no Brasil. Porto Alegre, EST, 1996, v. 3, pp. 534-554.

RIZZARDO, Redovino. Carlistas no Rio Grande do Sul. Porto Alegre, EST - CEPAM, 1981, 135p.

Raízes de um Povo. Porto Alegre, EST, 1990, 344p.

ROSOLI, Gianfausto. "Il Ruolo della Chiesa tra gli Emigrati Italiani in Rio Grande do Sul". Contributo alla Storia della Presenza Italiana in Brasile. Roma, Istituto Italo-Latino Americano, 1975, pp. 55-69.

RUBERT, Arlindo. Clero Secular Italiano no Rio Grande do Sul (1815-1930). Santa Maria, Pallotti, 1977, 150p.

SCALABRINI, João Batista. A Imigração Italiana na América. Porto Alegre,EST - CEPAM, 1979, 232p.

UGO, Gianluigi. Piccola Storia d'Italia. Perugia, Guerra, 1994, 151p. VILLA, Deliso. Storia Dimenticata. Porto Alegre, Sagra - DC Luzzatto, 1993, 250p.

ZAGONEL, Carlos Albino. Igreja e Imigração Italiana. Porto Alegre, EST, 1975, 285p.

Endereço do Autor: Caixa Postal 416 - Agência Central - Porto Alegre-RS - CEP 90.001-970 - E-mail: paulopossamai@bol.com.br 